\title{
A hybrid MCDA-LCA approach for assessing carbon foot-prints and environmental impacts of China's paper producing industry and printing services
}

\author{
Wencong Yue ${ }^{1}$, Yanpeng Cai ${ }^{1}{ }^{2 *}$, Qiangqiang Rong ${ }^{1}$, Lei Cao ${ }^{3}$ and Xumei Wang ${ }^{3}$
}

\begin{abstract}
Background: Labeling of carbon foot-prints (CFPS) for products and services is regarded as a convenient and effective method for reducing greenhouse gas (GHG) emissions. Life cycle analysis (LCA) is a useful tool for examine CFP of relevant products and services. However, the corresponding standards for CFP of products and services can hardly be satisfactorily adopted. Also, most of the previous studies were based on an individual indicator, which can hardly reflect multiple dimensions of sustainable implications of products and services.
\end{abstract}

Results: Thus, in this research, a hybrid life cycle analysis (LCA) and multi-criteria decision analysis (MCDA) method was proposed for helping evaluate CFP of products and services under multiple environmental indicators. The results indicated: (a) Air pollution caused by coal consumption was the primary environmental impact in China's paper-production industry, and (b) in printing industry, air pollution caused by VOC was the primary environmental impact in China. At the same time, CFP of $1,000 \mathrm{~kg}$ copying paper was $1,415.39 \mathrm{~kg} \mathrm{CO}_{2} \mathrm{e}$ based on $\mathrm{LCl}$ data of a paper factory in China. CFP of printing services was varied from each printing activity.

Conclusions: When purchasing copying paper, consumers should pay attention on coal consumption of the product. In printing industry, VOC of printing services should be taken serious consideration in China.

Keywords: Multi-criteria decision analysis; Life cycle analysis; Carbon foot-print; Copying paper; Printing services

\section{Background}

In the past decades, global market is becoming sensitive and responsive to environment-friendly technologies and services (Pineda-Henson et al. 2002). Accompanying with global endeavor to meet international commitments to reduce greenhouse gas (GHG) emissions, many consumers are eager to adopt an environmentally responsible living style to make a contribution to GHG emission reductions. Generally, it is not convenient for consumers to identify and single out products and services with reduced environmental impacts and GHG emissions. Therefore, propose of effective tools for helping consumers evaluate

\footnotetext{
* Correspondence: yanpeng.cai@bnu.edu.cn

'State Key Laboratory of Water Environment Simulation, School of Environment, Beijing Normal University, No. 19, XinJieKouWai St., HaiDian District, Beijing 100875, China

${ }^{2}$ Institute for Energy, Environment and Sustainable Communities, University of Regina, 120, 2 Research Drive, Regina, Saskatchewan S4S 7H9, Canada Full list of author information is available at the end of the article
}

environmental impacts and carbon credits of relevant products and services are desired.

Previously, many efforts were undertaken for estimating carbon foot-prints (CFPs) of products by the methods of LCA. For example, Zhao et al. (2011) established a CFPs analysis model based on energy consumption, and estimated the amount of carbon emissions due to the consumptions of fossil energy in many regions of China. Yuttitham et al. (2011) estimated CFPs for sugar production from sugarcane in eastern Thailand. Namy EspinozaOrias et al. (2011) estimated CFPs of breads that were produced and consumed in UK. Also, a number of papers presented the quantification of the uncertainties in estimating CFPs of a food product (Röös et al. 2010), plastic trays (Dormer et al. 2013) and shopping bags (Muthu et al. 2011). Among them, according to the Publicly Available Specification 2050 (i.e., PAS 2050) advanced by British Standards Institution (BSI 2008) in 2008, it was recommended that the method of life cycle analysis (LCA) be effective in evaluating CFPs of 
Table 1 Activity emission factor

\begin{tabular}{ll}
\hline & Activity emission factor \\
\hline China Southern Power Grid & $0.9787 \mathrm{~kg} \mathrm{CO}_{2} / \mathrm{kwh}$ \\
Coal & $0.974 \mathrm{~kg} \mathrm{CO} / \mathrm{kwh}$ \\
Diesel oil & $0.8733 \mathrm{~kg} \mathrm{CO} / \mathrm{kwh}$ \\
Natural gas & $0.9538 \mathrm{~kg} \mathrm{CO} / \mathrm{kg}$ \\
\hline
\end{tabular}

products and services. However, in the previous studies, CFP was merely adopted as an individual indicator which can hardly reflect multiple dimensions of sustainable implications of products and services (Schmoldt 2001; Schmidt 2009). There is a growing need for adopting effective tools that can be used to evaluate CFP of products and services considering multiple environmental indicators such as water pollution, air pollution, energy and resource consumption. To remedy this shortage, the Society for Environmental Toxicology and Chemistry (SETAC) favored the adoption of many Multi-Criteria Decision Making (MCDM) models (Pineda-Henson et al. 2002). It was recognized as an important tool in facilitating environmental decision making for formalizing and addressing the problem of competing decision objectives (Yatsalo et al. 2007; Regan et al. 2007; Linkov et al. 2006; Lahdelma et al. 2000). Among many MCDM methods, Analytic Hierarchy Process (AHP) was widely used by many researchers (Kaya and Kahraman 2011). However, there was a lack of studies that could hybrid AHP with LCA to help evaluate CFPs of products and services.

Therefore, in this paper, a hybrid LCA and AHP approach will be advanced for evaluating overall environmental impacts and CFPs of paper production and printing services in China. Firstly, AHP will be adopted to help rank environmental impacts of this industry and the relevant services, which will give an overall assessment on environmental impacts. The method of LCA will be used to estimate the detailed CFPs.

\section{Overview of copying-paper production in China}

Pulp and paper making, a wastewater discharge intensive sector, has long been among the major water polluters in China. In 2009, for example, this sector discharged $18.8 \%, 28.9 \%$, and $11.2 \%$ of national industrial wastewater,
COD, and $\mathrm{NH}_{3}-\mathrm{N}$ emission loadings, respectively (NBS and MEP 2010). These values are partially attributable to the fact that paper consumption has been soaring with China's rapid economic growth over the last decade. Gross consumption of paper and paper board, for example, increased from 35.75 million tons in 2000 to 110.11 million tons in 2011, with an average annual growth rate of $6.1 \%$ (Zhang et al. 2012; NBS 2012). More recently, a greater number of studies highlighted energy consumption and greenhouse gas (GHG) emissions from the pulp and paper sector at global or national levels because of increasing concern on climate change (Zhang et al. 2012; Szabóa et al. 2009; Möllersten et al. 2003; Kallio et al. 2004; Davidsdottir and Ruth 2004).

\section{Results and discussion}

CFP of copying paper and printing services

1) Activity emission factor

According to relevant research result from IPCC (IPCC 2006), Ecoinvent databases and Chen S (Sha et al. 2012), the activity emission factors were listed in Table 1.

2) CFP of copying paper in China Using the model described in Section 2.2, the cradle-to-grave CFP of $1000 \mathrm{~kg}$ of copying paper was found to be $1415.39 \mathrm{~kg} \mathrm{CO} 2 \mathrm{e}$. The contribution of the various life cycle inventories were showed in Table 2.

3) CFP of Printing services in China Using the model described in Section 2.2, the cradle-to-grave CFP of printing services for one book was found to be $5.249 \mathrm{~kg} \mathrm{CO}$ e. The contribution of the various life cycle inventories were showed in Table 3, and CFP of services for printing a book was showed in Table 4.

\section{AHP of paper and printing industries}

The hierarchy tree was presented in Figures 1 and 2 . The goal, which was ranking environmental impacts of paper and printing industries, was given at the first level (level 1). There were four main criteria presented in level 2 of the hierarchy, which were water pollution, air

Table 2 Life cycle inventories of producing $1000 \mathrm{~kg}$ copying paper in a paper-making factory of China

\begin{tabular}{|c|c|c|c|c|c|c|}
\hline & & \multicolumn{4}{|c|}{ Technological process } & \multirow[t]{2}{*}{ Total } \\
\hline & & Pulping & Beating & Forming \& pressing & Treating wastewater & \\
\hline & Coal- kg & - & $7.58 \mathrm{E}+01$ & $6.20 \mathrm{E}+02$ & $1.27 \mathrm{E}+01$ & $7.76 E+02$ \\
\hline & Crude oil- kg & - & - & - & - & 4.38E + 01 \\
\hline \multirow[t]{3}{*}{ Resource consumption } & Diesel oil- kg & 6.99 & - & - & - & $7.11 E+00$ \\
\hline & Natural gas- $\mathrm{m}^{3}$ & $1.43 E+01$ & - & - & - & $1.43 \mathrm{E}+01$ \\
\hline & Timber- kg & $4.20 \mathrm{E}+02$ & $1.32 \mathrm{E}+03$ & - & - & $1.74 \mathrm{E}+03$ \\
\hline
\end{tabular}


Table 3 Life cycle inventory of electricity printing services in a printing factory of China

\begin{tabular}{|c|c|c|c|c|c|}
\hline \multicolumn{2}{|c|}{ Technological process } & \multicolumn{2}{|l|}{ Quantity } & \multirow{2}{*}{$\frac{\text { Unit }}{\text { kwh }}$} & \multirow{2}{*}{$\begin{array}{l}\text { Functional unit } \\
1 \text { piece of printing plate }\end{array}$} \\
\hline \multirow{4}{*}{ Pre-press } & Designing & China Southern power grid & 0.571 & & \\
\hline & & Diesel generator of the factory itself & $8.16 \mathrm{E}-04$ & kwh & \\
\hline & Plate-making & China Southern power grid & 0.715 & kwh & \\
\hline & & Diesel generator of the factory itself & 2.77E-03 & kwh & \\
\hline \multirow{2}{*}{ Printing } & & China Southern power grid & 0.0302 & kwh & \multirow{2}{*}{1 sheet for printing paper } \\
\hline & & Diesel generator of the factory itself & 8.47E-05 & kwh & \\
\hline \multirow{3}{*}{ Post-press } & Bookbinding & China Southern power grid & $2.13 \mathrm{E}-03$ & kwh & \\
\hline & & Diesel generator of the factory itself & $1.13 \mathrm{E}-05$ & kwh & 1 sheet for printing paper \\
\hline & Storage & China Southern power grid & 1.01E-04 & $\mathrm{kg}$ & \\
\hline
\end{tabular}

Table 4 CFP of printing services taking a book as an example

\begin{tabular}{llll}
\hline Stage & $\begin{array}{l}\text { CE of 1 } \\
\text { functional } \\
\text { unit }\end{array}$ & Functional unit & $\begin{array}{l}\text { Unit: kg CO } \\
\text { CE of a book }\end{array}$ \\
\hline Pre-press & 2.450 & 1 sheet of plate & 26.95 \\
Printing & 0.339 & 1 sheet of paper & 3.729 \\
Post-press & 0.0207 & 1 sheet of paper & 0.2277 \\
Total & 5.249 & & \\
\hline
\end{tabular}

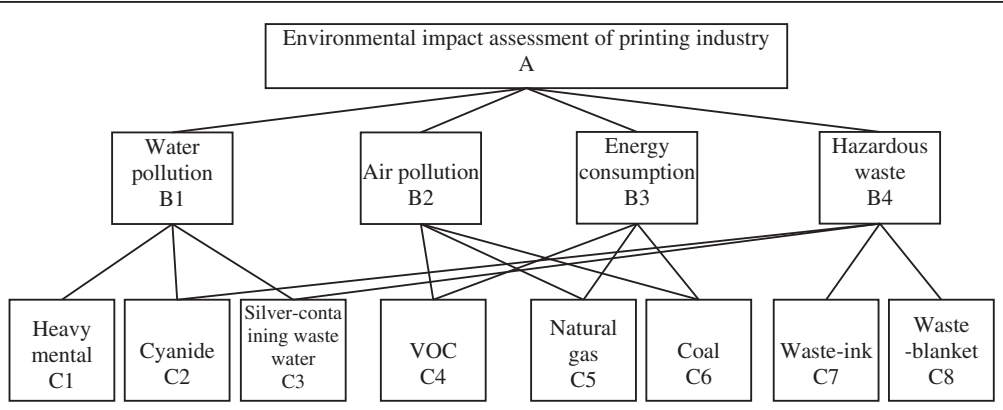

Figure 1 Hierarchy tree for environmental impact assessment of printing industry.

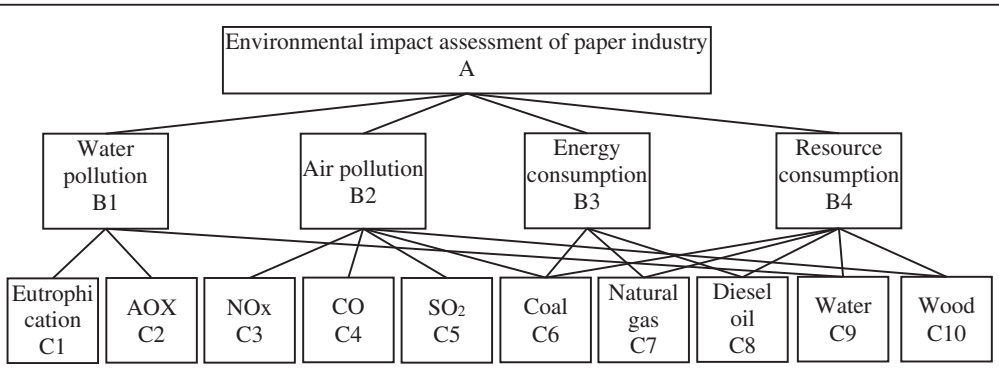

Figure 2 Hierarchy tree for environmental impact assessment of paper-making industry. 
Table 5 Pair-wise evaluation of level 2 of paper-making industry

\begin{tabular}{lllllll}
\hline A & B1 & B2 & B3 & B4 & W' $^{\prime}$ & Priorities \\
\hline B1 & 1 & 3 & 0.5 & 0.33 & 0.84 & 0.155 \\
B2 & 0.33 & 1.00 & 0.17 & 0.11 & 0.37 & 0.068 \\
B3 & 2.00 & 6.00 & 1.00 & 0.67 & 1.68 & 0.311 \\
B4 & 3.00 & 9.00 & 1.50 & 1.00 & 2.52 & 0.466 \\
\hline$\lambda_{\max }=4.25, C l=0.08, \mathrm{Rl}=0.9, \mathrm{CR}=0.09$. & & &
\end{tabular}

Table 6 Pair-wise evaluation of level 3 of paper-making industry (1)

\begin{tabular}{llllll}
\hline B1 & C1 & C2 & C9 & W' $^{\prime}$ & Priorities \\
\hline C1 & 1.00 & 0.60 & 3.00 & 1.22 & 0.33 \\
C2 & 1.67 & 1 & 5 & 2.03 & 0.56 \\
C9 & 0.33 & 0.20 & 1 & 0.41 & 0.11 \\
\hline
\end{tabular}

$\lambda_{\max }=3, \mathrm{Cl}=0, \mathrm{Rl}=0.58, \mathrm{CR}=0$.

Table 7 Pair-wise evaluation of level 3 of paper-making industry (2)

\begin{tabular}{llllllll}
\hline $\mathbf{B}_{\mathbf{2}}$ & $\mathbf{C 3}$ & $\mathbf{C 4}$ & $\mathbf{C 5}$ & $\mathbf{C 6}$ & $\mathbf{C 1 0}$ & $\mathbf{W}^{\prime}$ & Priorities \\
\hline C3 & 1.00 & 1.00 & 0.33 & 0.20 & 0.14 & 0.394 & 0.059 \\
C4 & 1.00 & 1.00 & 0.33 & 0.20 & 0.14 & 0.394 & 0.059 \\
C5 & 3.00 & 3.00 & 1.00 & 0.60 & 0.43 & 1.183 & 0.177 \\
C6 & 5.00 & 5.00 & 1.67 & 1.00 & 0.71 & 1.971 & 0.294 \\
C10 & 7.00 & 7.00 & 2.33 & 1.40 & 1.00 & 2.760 & 0.412 \\
\hline
\end{tabular}

$\lambda_{\max }=5.001, \mathrm{Cl}=0.0003, \mathrm{Rl}=1.12, \mathrm{CR}=0.00028$.

Table 8 Pair-wise evaluation of level 3 of paper-making industry (3)

\begin{tabular}{llllll}
\hline B3 & C6 & C7 & C8 & W' $^{\prime}$ & Priorities \\
\hline C6 & 1.00 & 1.67 & 5.00 & 2.027 & 0.555 \\
C7 & 0.60 & 1.00 & 3.00 & 1.216 & 0.333 \\
C8 & 0.20 & 0.33 & 1.00 & 0.405 & 0.111 \\
\hline
\end{tabular}

$\lambda_{\max }=3, \mathrm{Cl}=0, \mathrm{Rl}=0.58, \mathrm{CR}=0$.

Table 9 Pair-wise evaluation of level 3 of paper-making industry (4)

\begin{tabular}{llllllll}
\hline B4 & C6 & C7 & C8 & C9 & C10 & W' & Priorities \\
\hline C6 & 1.00 & 1.67 & 5.00 & 0.83 & 0.71 & 1.38 & 0.23 \\
C7 & 0.60 & 1.00 & 3.00 & 0.50 & 0.43 & 0.83 & 0.14 \\
C8 & 0.20 & 0.33 & 1.00 & 0.17 & 0.14 & 0.28 & 0.05 \\
C9 & 1.20 & 2.00 & 6.00 & 1.00 & 0.86 & 1.65 & 0.27 \\
C10 & 1.40 & 2.33 & 7.00 & 1.17 & 1.00 & 1.93 & 0.32 \\
\hline
\end{tabular}

$\lambda_{\max }=5.001, \mathrm{Cl}=0, \mathrm{Rl}=1.12, \mathrm{CR}=0$.
Table 10 Pair-wise evaluation of level 2 of printing industry

\begin{tabular}{lllllll}
\hline $\mathbf{a}$ & B1 & B2 & B3 & B4 & W' & Priorities \\
\hline B1 & 1 & 0.60 & 3.00 & 0.43 & 0.94 & 0.19 \\
B2 & 1.67 & 1.00 & 5.00 & 0.71 & 1.56 & 0.31 \\
B3 & 0.33 & 0.20 & 1.00 & 0.14 & 0.31 & 0.06 \\
B4 & 2.33 & 1.40 & 7.00 & 1.00 & 2.19 & 0.44 \\
\hline$\lambda_{\max }=4, C l=0, \mathrm{Rl}=0.9, C R=0$. & & & &
\end{tabular}

Table 11 Pair-wise evaluation of level 3 of printing industry (1)

\begin{tabular}{llllll}
\hline B1 & C1 & C2 & C3 & W' & Priorities \\
\hline C1 & 1.00 & 1.67 & 5.00 & 2.03 & 0.56 \\
C2 & 0.60 & 1.00 & 3.00 & 1.22 & 0.33 \\
C3 & 0.20 & 0.33 & 1.00 & 0.41 & 0.11 \\
\hline
\end{tabular}

$\lambda_{\max }=3, \mathrm{Cl}=0, \mathrm{Rl}=0.58, \mathrm{CR}=0$.

Table 12 Pair-wise evaluation of level 3 of printing industry (2)

\begin{tabular}{llllll}
\hline B2 & C4 & C5 & C6 & W' $^{\prime}$ & Priorities \\
\hline C4 & 1.00 & 2.33 & 7.00 & 2.537 & 0.636 \\
C5 & 0.43 & 1.00 & 3.00 & 1.087 & 0.273 \\
C6 & 0.14 & 0.33 & 1.00 & 0.362 & 0.091 \\
\hline
\end{tabular}

$\lambda_{\max }=3, \mathrm{Cl}=0, \mathrm{Rl}=0.58, \mathrm{CR}=0$.

Table 13 Pair-wise evaluation of level 3 of printing industry (3)

\begin{tabular}{llllll}
\hline B3 & C4 & C5 & C6 & W1 & Priorities \\
\hline C4 & 1.00 & 4.00 & 1.33 & 1.747161 & 0.518445 \\
C5 & 0.25 & 1.00 & 0.33 & 0.43679 & 0.129611 \\
C6 & 0.75 & 3.00 & 1.00 & 1.310371 & 0.388834 \\
\hline$\lambda_{\max }=3.003, \mathrm{Cl}=0.002, \mathrm{Rl}=0.58, \mathrm{CR}=0.003$. & &
\end{tabular}

Table 14 Pair-wise evaluation of level 3 of printing industry (4)

\begin{tabular}{lllllll}
\hline B4 & C2 & C3 & C8 & C10 & W' & Priorities \\
\hline C2 & 1.00 & 1.67 & 5.00 & 3.00 & 2.24 & 0.51 \\
C3 & 0.60 & 1.00 & 3.00 & 1.00 & 1.16 & 0.26 \\
C8 & 0.20 & 0.33 & 1.00 & 1.00 & 0.51 & 0.12 \\
C10 & 0.20 & 0.33 & 1.00 & 1.00 & 0.51 & 0.12 \\
\hline
\end{tabular}


Table 15 Weighs of environmental factors of paper-making industry

\begin{tabular}{llllll}
\hline Factor & Water pollution & Air pollution & Energy consumption & \multicolumn{2}{l}{ Resource consumption } \\
& $\mathbf{0 . 1 5 5}$ & $\mathbf{0 . 0 6 8}$ & $\mathbf{0 . 3 1 1}$ & $\mathbf{0 . 4 6 6}$ \\
\hline Eutrophication & 0.33 & - & - & - & - \\
$\mathrm{AOX}$ & 0.56 & - & - & - & 0.051 \\
$\mathrm{NOx}$ & - & 0.059 & - & - & 0.087 \\
$\mathrm{CO}$ & - & 0.059 & - & - & 0.004 \\
$\mathrm{SO}_{2}$ & - & 0.177 & - & 0.23 & 0.004 \\
$\mathrm{Coal}$ & - & 0.294 & 0.556 & 0.14 & 0.012 \\
natural gas & - & - & 0.333 & 0.05 & 0.300 \\
diesel oil & - & - & 0.111 & 0.32 & 0.169 \\
Wood & - & 0.412 & - & 0.27 & 0.058 \\
Water & 0.11 & - & - & 0.173 \\
\hline
\end{tabular}

pollution, energy consumption and resource consumption of paper-making industry and water pollution, air pollution, energy consumption and hazardous waste of printing industry. Level 2 of the hierarchy were further divided into several sub-criteria, which were showed in level 3. The results of comparison of level 2 in paper-making industry are shown in Table 5 . Also, the results of level 3 in paper-making industry are shown in Tables 6 to 9. Moreover, the results of comparison of level 2 in printing industry are shown in Table 10. Correspondingly, the results of level 3 in printing industry are shown in Tables 11 to 14 .

After pair-wise comparisons between elements at each level, the weights of environmental factors can be calculated (see Tables 15 and 16). Results of AHP of paper-making and printing industries in China were: (a) Air pollution caused by coal consumption was the primary environmental impact in China's paper-production industry, and (b) in printing industry, air pollution caused by VOC was the primary environmental impact in China.

\section{Conclusions}

This study demonstrated that the integrated LCA and MCDA approach provided a structured and comprehensive methodology for impact analysis and environmental decision making. In the background of growing concerns over global warming, carbon emission became an important factor. Carbon footprint, however, should not be merely one element in decision-making. The developed method could thus improve previous studies in comprehensive assessment on carbon footprints of products and service on multiple issues. The developed method was then applied to copying paper and printing services of China. The application indicated that the hybrid MCDA-LCA method can provide a structured and comprehensive methodology for accounting CFP as well as assessing environmental impacts of products and services. The results indicated that the most emergent environmental impacts caused by paper production and printing services were resource consumption and hazardous waste. At the same time, due to a lack of lifecycle inventory data of planting trees, carbon storage was not included in system boundary of copying paper. The next study would be furthered in detailed carbon emission of paper-making industry. Moreover, when purchasing copying paper, consumers should pay attention on coal consumption of the product. In printing

Table 16 Weighs of environmental factors of printing services

\begin{tabular}{llllll}
\hline Factor & $\begin{array}{l}\text { Water } \\
\text { pollution }\end{array}$ & $\begin{array}{l}\text { Air } \\
\text { pollution }\end{array}$ & $\begin{array}{l}\text { Energy } \\
\text { consumption }\end{array}$ & $\begin{array}{l}\text { Hazardous } \\
\text { Waste }\end{array}$ \\
& $\mathbf{0 . 1 9 0}$ & $\mathbf{0 . 3 1 0}$ & $\mathbf{0 . 0 6 0}$ & $\mathbf{0 . 4 4 0}$ \\
\hline heavy metal & 0.560 & - & - & - & 0.106 \\
Cyanide & 0.330 & - & - & 0.250 & 0.173 \\
silver-containing waste water & 0.110 & - & - & - & -200 \\
VOC & - & 0.636 & 0.500 & - & 0.109 \\
natural gas & - & 0.273 & 0.125 & 0.227 \\
Coal & - & 0.091 & - & 0.375 & 0.092 \\
waste-ink & - & - & - & 0.090 & 0.051 \\
waste-blanket & - & - & & & 0.040 \\
\hline
\end{tabular}




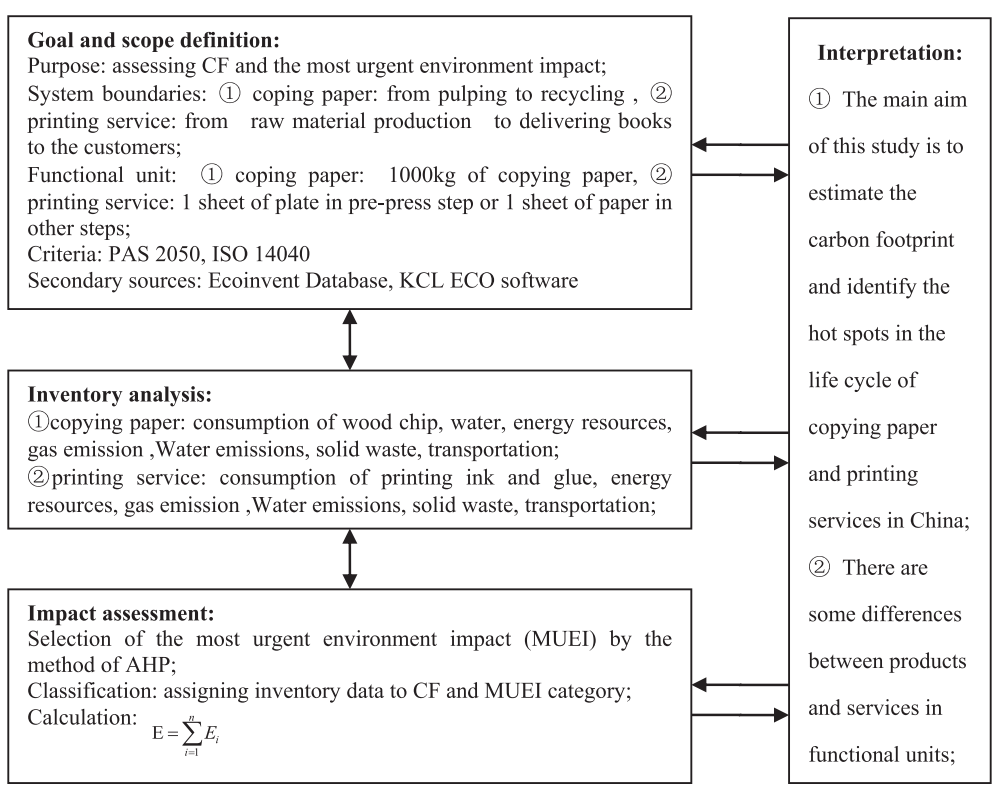

Figure 3 LCA phases of copying paper and printing services.

industry, VOC of printing services should be taken serious consideration in China.

\section{Methods}

This study was performed by a methodological framework based on hybrid LCA and AHP.

\section{Life cycle assessment}

Life-cycle assessment (LCA) is a method that builds on factual information and models of natural processes (Hertwich and Hammitt 2001). LCA is an increasingly important tool for environmental policy, and even for industry (Ayres 1995). The Society of Environmental Toxicology and Chemistry and the International Organization for Standardization developed the LCA methodology in the 1990s. The methodology is included under the international standards ISO 14040 series (Nanaki and Koroneos 2012), which are list in the following.

(1) ISO 14040:2006 Environmental management - Life cycle assessment - Principles and framework;

(2) ISO 14044:2006 Environmental management - Life cycle assessment - Requirements and guidelines;

Table 17 Functional units of printing services

\begin{tabular}{ll}
\hline Phases & Functional unit \\
\hline Pre-press & 1 piece of printing plate \\
Printing & 1 sheet for printing paper \\
Post-press & 1 sheet for printing paper \\
\hline
\end{tabular}

(3) ISO/TR 14047:2003 Environmental management Life cycle impact assessment - Examples of application of ISO 14042;

(4) ISO/TS 14048:2002 Environmental management Life cycle assessment - Data documentation format

There have also been developments on the standardization on the application of LCA-based methods for design purposes (Regan et al. 2007; ISO 2006). The Society of Environmental Toxicology and Chemistry's (SETAC) "Code of practice" originally distinguished four methodological components within LCA: goal and scope definition, life cycle inventory analysis, life cycle impact assessment, and life cycle improvement assessment. In ISO14040 (ISO 1997) life cycle improvement assessment is no longer regarded as a phase on its own, but rather as having an influence throughout the whole LCA methodology. In addition, life cycle interpretation has been introduced. This is a phase that interacts with all other phases in the LCA procedure, as illustrated in Figure 2.

Along with the increasing concerns over global warming, greenhouse gas (GHG) emissions arising from products (goods and services) are assessed by the help of life cycle assessment (LCA). Publicly Available Specification 2050:2008, Specification for the assessment of the life cycle greenhouse gas emissions of goods and services (BSI 2008) is regarded as a mechanism for simplifying and standardizing the methods for assessing the carbon footprint of products and services (Sinden 2009).

According to ISO 14044 (ISO 2006) and PAS2050, LCA phases of copying paper and printing service are divided into four phases: goal and scope definition, 


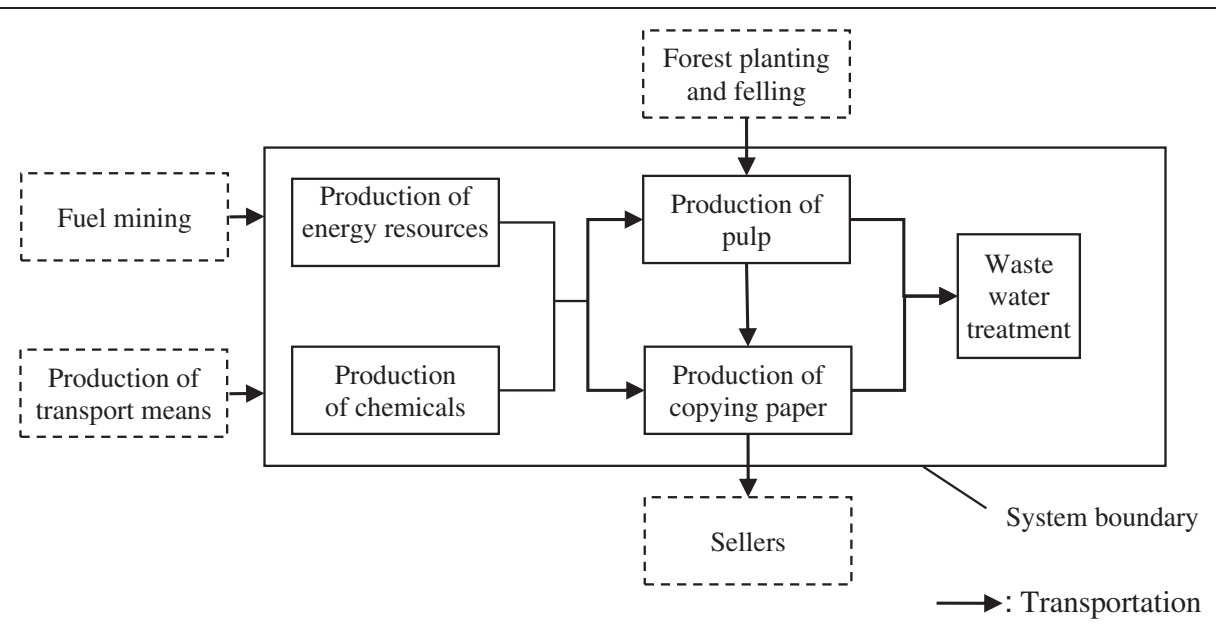

Figure 4 System boundary of copying paper.

inventory analysis, impact assessment and interpretation (see Figure 3).

\section{Goal and scope of the study}

The main aim of this study is to estimate the carbon footprint and identify the hot spots in the life cycle of copying paper and printing services in China. Products of copying paper and printing services of study are presented. The functional unit of copying paper is $1000 \mathrm{~kg}$. There are some differences between products and services in functional units. The functional units of services are not single and fixed. In another word, the functional units of services are changed along with the phases of services. In this paper, there are two functional units in printing services (see Table 17).

\section{System boundaries and system definition}

The system boundaries of copying paper, showed in Figure 4, include the following parts:

(1) Production of pulp

(2) Transport pulp to paper mills

(3) Paper-making process, including repulping, furnishing, forming and pressing, (1) (4) cutting and packing

(4) Waste water treatment

(5) Energy production

(6) Chemicals production

(7) Transport of copying paper to sellers

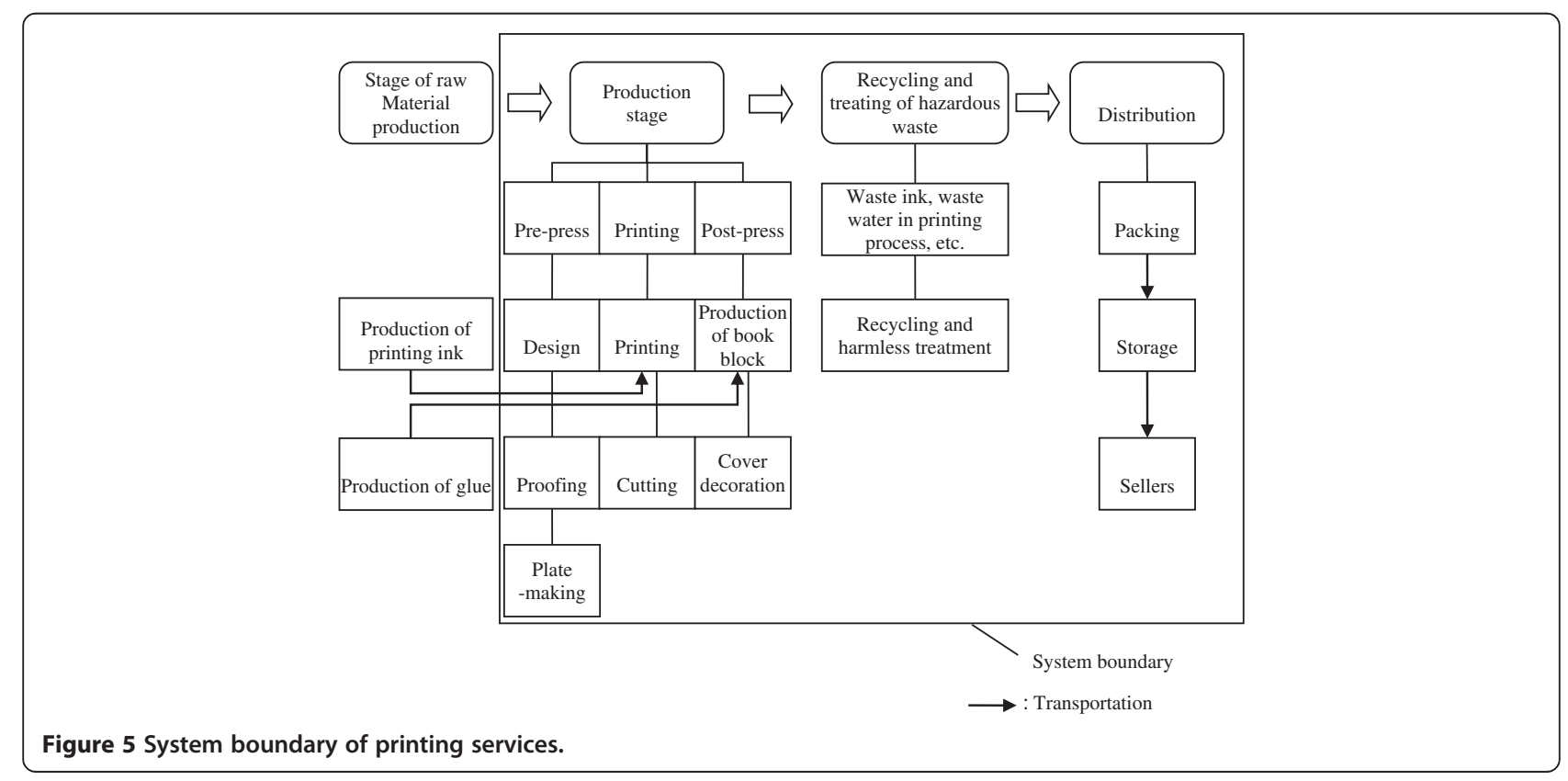


As shown in Figure 5, the following stages are included within the system boundary:

(1)Raw materials: producing printing ink and glue

(2) Processing: pre-press, printing and post-press stages in printing process

(3)Distribution stage: packing, storage, proofing and transporting to sellers

(4) Recycling and treating of hazardous waste

\section{CFP calculation}

The CFP of an activity is calculated by multiplying the activity data and the emission factor together (BSI 2008). The total CFP is calculated by then summing the individual CFPs for all activities within the specified life cycle as outlined in Eq. (1):

$$
\text { Carbon footprint }=\sum_{\times \text {Activity emission factor }} \text { Activity data }
$$

\section{Analytic hierarchy process}

The Analytic Hierarchy Process (AHP) is a general theory for measurement (Saaty 1987). The method of AHP is designed for multiple-criteria decisions (Schmoldt 2001). Three important components of AHP are: (1) the structuring of a problem into a hierarchy, which consisting of a goal and subordinate features (decomposition), (2) pairwise comparisons between elements at each level (evaluation) and (3) propagation of level-specific, local priorities to global priorities (synthesis) (Schmoldt 2001). In methods of AHP, the elements in each level are compared pair wise with respect to their importance in making the decision that is under consideration (Dey 2002). The scale of integers in the range 1-9 is used for comparison (Schmoldt 2001; Saaty 1990). From the set of pair wise comparisons of the elements, a judgment matrix is generated with $n$ rows and $n$ columns, where $n$ is the number of elements being considered (Pineda-Henson et al. 2002). In the matrix $\alpha_{i j}$ indicates how much more important row heading is than column heading $\mathrm{j}$ (Schmoldt 2001):

$$
\begin{aligned}
& W_{i}^{\prime}=\sqrt[n]{\prod_{i=1}^{n} \alpha_{i j}}(i=1,2, \ldots, n) \\
& W_{i}=\frac{W_{i}^{\prime}}{\sum_{i=1}^{n} W_{i}^{\prime}}
\end{aligned}
$$

The measure of consistency of an AHP judgment matrix is determined by considering the judgment matrix with $n$ rows and $n$ columns where $\alpha_{\mathrm{ij}}=\frac{1}{\alpha_{\mathrm{ji}}}$, all $\alpha_{\mathrm{ij}} \geq 0$, and pi as the corresponding AHP priorities Ruby PH et al. (Pineda-
Henson et al. 2002)provides an approximate way of calculating the maximum eigenvalue $\lambda_{\max }$ :

$$
\lambda_{\max }=\mathrm{W}_{1} \sum_{i=1}^{n} \alpha_{i 1}+\mathrm{W}_{2} \sum_{i=1}^{n} \alpha_{i 2}+\cdots+W_{\mathrm{n}} \sum_{i=1}^{n} \alpha_{i n}
$$

The judgment matrix has an eigenvalue equal to $\mathrm{n}$ if the comparisons are perfectly consistent. The largest eigenvalue, $\lambda_{\max }$, is greater than $\mathrm{n}$ if the comparisons are not perfectly consistent. The difference between $\lambda_{\max }$ and $\mathrm{n}$ is expressed by Saaty (2001) as the consistency index (CI), which is computed as:

$$
\mathrm{CI}=\left(\lambda_{\max }-\mathrm{n}\right) /(\mathrm{n}-1)
$$

The $\mathrm{CI}$ is compared to the corresponding random consistency indices (RI) developed by Saaty (2001). The consistency ratio $(\mathrm{CR})$ is computed from:

$$
\mathrm{CR}=\mathrm{CI} / \mathrm{RI}
$$

Saaty (Saaty 1990) recommends that the ratings from the experts may be accepted if the consistency ratio of the pair-wise comparison matrix is less than or equal to 0.10 (i.e., $90 \%$ consistent or $10 \%$ inconsistent). Otherwise, it is recommended that the pair-wise comparisons be revised to improve the consistency of these comparisons.

\section{Competing interests}

The authors declare that they have no competing interests.

\section{Authors' contributions}

The work presented here was carried out in collaboration between al authors. YUE WC and CAI YP explored the hybrid LCA-MCDA approach. YUE WC, RONG QQ, CAO L and WANG XM provided the case study for calculating CFP of the product and services. All authors have contributed to the paper preparation, and have seen and approved the manuscript.

\section{Acknowledgements}

This research was supported by the special fund of State Key Lab of Water Environment Simulation (11Z01ESPCN), the National Science Foundation for Innovative Research Group (No. 51121003) and the Twelfth Five-Year National Science and Technology Project (No. 2011BAC04B03).

\section{Author details}

${ }^{1}$ State Key Laboratory of Water Environment Simulation, School of Environment, Beijing Normal University, No. 19, XinJieKouWai St., HaiDian District, Beijing 100875, China. ${ }^{2}$ Institute for Energy, Environment and Sustainable Communities, University of Regina, 120, 2 Research Drive, Regina, Saskatchewan S4S 7H9, Canada. ${ }^{3}$ Environmental Development Centre of Ministry of Environmental Protection, No. 1 YuhuinanluChaoyang District, Beijing 100029, China.

Received: 25 November 2013 Accepted: 23 December 2013

Published: 16 January 2014

\section{References}

Ayres RU (1995) Life-cycle analysis - a critique. Resour Conserv Recycling 14(3-4):199-223, Doi:10.1016/0921-3449(95)00017-d

BSI (2008) PAS 2050: 2008-Specification for the Assessment of the Life Cycle Greenhouse Gas Emissions of Goods and Services. BSI Group. London, London

Davidsdottir B, Ruth M (2004) Capital vintage and climate change policies: the case of US pulp and paper. Environ Sci Policy 7(3):221-233, doi:10.1016/j. envsci.2004.02.007 
Dey PK (2002) Project risk management: a combined analytic hierarchy process and decision tree approach. Cost Eng 44(3):13-27

Dormer A, Finn DP, Ward P, Cullen J (2013) Carbon footprint analysis in plastics manufacturing. Journal of Cleaner Production 51:133-141, doi:10.1016/j. jclepro.2013.01.014

Espinoza-Orias N, Stichnothe H, Azapagic A (2011) The carbon footprint of bread. Int J Life Cycle Assess 16(4):351-365, doi:10.1007/s11367-011-0271-0

Hertwich EG, Hammitt JK (2001) A decision-analytic framework for impact assessment - part I: LCA and decision analysis. Int J Life Cycle Assess 6(1):5-12, doi:10.1065/lca2000.08.031

IPCC (2006) IPCC Guidelines for national greenhouse gas inventories. Institute for Global Environmental Strategies (IGES), Hayama, Japan

ISO (1997) 14040. Environmental management-Life cycle assessment-Principles and framework. International Organization for Standardization. ISO Central Secretariat, Switzerland

ISO (2006) 14044: environmental management—life cycle assessment—requirements and guidelines. International Organization for Standardization, ISO Central Secretariat, Switzerland

Kallio AMI, Moiseyev A, Solberg B (2004) The global forest sector model EFI-GTM: the model structure. European Forest Institute Joensuu, Joensuu

Kaya T, Kahraman C (2011) Fuzzy multiple criteria forestry decision making based on an integrated VIKOR and AHP approach. Expert Syst Appl 38(6):7326-7333, doi:10.1016/j.eswa.2010.12.003

Lahdelma R, Salminen P, Hokkanen J (2000) Using multicriteria methods in environmental planning and management. Environ Manage 26(6):595-605, do: $10.1007 / 5002670010118$

Linkov I, Satterstrom FK, Kiker G, Batchelor C, Bridges T, Ferguson E (2006) From comparative risk assessment to multi-criteria decision analysis and adaptive management: recent developments and applications. Environ Int 32(8):1072-1093, do:10.1016/.jenvint.2006.06.013

Möllersten K, Yan J, Westermark M (2003) Potential and cost-effectiveness of $\mathrm{CO}_{2}$ reductions through energy measures in Swedish pulp and paper mills. Energy 28(7):691-710, doi:10.1016/s0360-5442(03)00002-1

Muthu SS, Li Y, Hu JY, Mok PY (2011) Carbon footprint of shopping (grocery) bags in China, Hong Kong and India. Atmos Environ 45(2):469-475, doi:10.1016/j.atmosenv.2010.09.054

Nanaki EA, Koroneos CJ (2012) Comparative LCA of the use of biodiesel, diesel and gasoline for transportation. J Cleaner Prod 20(1):14-19, doi:10.1016/j. jclepro.2011.07.026

National Bureau of Statistics (NBS) of China and Ministry of Environmental Protection (MEP) of China (2010) China statistical yearbook on environment 2010. China Statistics Press, Beijing

National Bureau of Statistics (NBS) of China (2012) China statistical yearbook 2012 , 2012-09-01st edn. China Statistics Press, Beijing

Pineda-Henson R, Culaba AB, Mendoza GA (2002) Evaluating environmental performance of pulp and paper manufacturing using the analytic hierarchy process and life-cycle assessment. Journal of Industrial Ecology 6(1):15-28, doi:10.1162/108819802320971614

Regan HM, Davis FW, Andelman SJ, Widyanata A, Freese M (2007) Comprehensive criteria for biodiversity evaluation in conservation planning. Biodivers Conserv 16(9):2715-2728, doi:10.1007/s10531-006-9100-3

Röös E, Sundberg C, Hansson P-A (2010) Uncertainties in the carbon footprint of food products: a case study on table potatoes. Int I Life Cycle Assess 15(5):478-488, doi:10.1007/s11367-010-0171-8

Saaty TL (1987) How to handle dependence with the analytic hierarchy process. Mathematical Modelling 9(3-5):369-376, doi:10.1016/0270-0255(87)90494-5

Saaty TL (1990) How to make a decision: The analytic hierarchy process. European Journal of Operational Research 48(1):9-26, doi:http://dx.doi.org/ 10.1016/0377-2217(90)90057-1

Saaty TL (2001) Decision Making for Leaders: The Analytic Hierarchy Process for Decisions in a Complex World: 1999/2000 Edition, vol 2. RWS Publications, Pittsburgh

Schmidt H-J (2009) Carbon footprinting, labelling and life cycle assessment. Int J Life Cycle Assess 14(1):6-9, doi:10.1007/s11367-009-0071-y

Schmoldt DL (2001) The analytic hierarchy process in natural resource and environmental decision making, vol 3. Springer, Dordrecht

Sha C, Li-juan R, Shui-yuan C, Zun-wen L, Cai-hua Z, Wen-cong Y (2012) Life cycle inventory study of thermal electric generation in china. Natural Gas 38931(15.3):56-51
Sinden G (2009) The contribution of PAS 2050 to the evolution of international greenhouse gas emission standards. Int J Life Cycle Assess 14(3):195-203, doi:10.1007/s11367-009-0079-3

Szabóa L, Soriaa A, Forsströmb J, Keränenb JT, Hytönenb E (2009) A world model of the pulp and paper industry: demand, energy consumption and emission scenarios to 2030. Environmental Science \& Policy 12(3):257-269, doi:10.1016/j.envsci.2009.01.011

Yatsalo BI, Kiker GA, Kim SJ, Bridges TS, Seager TP, Gardner K, Satterstrom FK, Linkov I (2007) Application of multicriteria decision analysis tools to two contaminated sediment case studies. Integr Environ Assess Manag 3(2):223-233, doi:10.1897/ieam_2006-036.1

Yuttitham M, Gheewala SH, Chidthaisong A (2011) Carbon footprint of sugar produced from sugarcane in eastern Thailand. Journal of Cleaner Production 19(17-18):2119-2127, doi:10.1016/j.jclepro.2011.07.017

Zhang C, Chen J, Wen Z (2012) Alternative policy assessment for water pollution control in China's pulp and paper industry. Resources Conservation and Recycling 66:15-26, doi:10.1016/j.resconrec.2012.06.004

Zhao R, Huang X, Zhong T, Peng J (2011) Carbon footprint of different industrial spaces based on energy consumption in China. Journal of Geographical Sciences 21(2):285-300, doi:10.1007/s11442-011-0845-6

doi:10.1186/2193-2697-3-4

Cite this article as: Yue et al: A hybrid MCDA-LCA approach for assessing carbon foot-prints and environmental impacts of China's paper producing industry and printing services. Environmental Systems Research 2014 3:4.

\section{Submit your manuscript to a SpringerOpen ${ }^{\circ}$ journal and benefit from:}

- Convenient online submission

- Rigorous peer review

- Immediate publication on acceptance

- Open access: articles freely available online

- High visibility within the field

- Retaining the copyright to your article

Submit your next manuscript at $>$ springeropen.com 